\title{
44
}

\section{CONTAMINATED LAND SITUATION IN FINLAND}

Jukka Nevalainen

Regional Environmental Agency of Häme

Finland

\begin{abstract}
Contaminated land sites in Finland was investigated in the beginning of 1990's. About 10000 sites were suspected to be polluted. Typical cases of soil contamination are sawmills, wood impregnation plants, waste treatment plants, garages and scrap yards. It is estimated that about 1200 sites need remediation actions. Estimated costs of restoration are FIM 5.4 billion over the next 20 years. Legislation has been changed to concern soil pollution. However old and hostless contaminated soil sites have legal and economic problems. The resources meant to solve soil pollution have increased rapidly during last years in Finland.
\end{abstract}

\section{INTRODUCTION}

Soil contamination has given rise to serious concern in Finland in the 1980's. Several cases of groundwater pollution were pointed caused by the disposal of waste and chemicals onto land. In its environmental report submitted to Parliament in 1988, the Government promised that extent of polluted land areas would be assessed and remedial measures taken where necessary. An internal programme, the SAMASE-project, set up for that purpose by the environmental authories.

Contaminated soil areas were assessed by thirteen Water and Environment Districts's (nowadays Regional Environmental Agencies) researchers. The National Board of Waters and Environment collected the material from districts and made the final report (Puolanne et al., 1994). The work was done during 1990-93. In connection with main project there were many smaller $R \& D$-projects to promote contaminated soil area surveys and remedition works in the future. Soil protection has after SAMASE-project been the most developing environmental research area or business activity in Finland. 


\section{CONTAMINATED SOIL SITES IN FINLAND}

Together with municipal environmental authorities, the water and environmental districts complied data on land suspected of being polluted. Altogether 10400 sites were entered in a register. If all small and minor sites had been included, the register would have held some 25000 sites.

Typical cases of soil contamination were caused by garages, scrap yards, waste treatment plants, sawmills and wood impregnation plants. More than 2000 of the sites are in groundwater areas and 1600 are close to residential areas. It is clear that only three year investigation time during the SAMASE-project was too short to give absolute answer contaminated soil situation in Finland. About $90 \%$ of all sites were designated as 'probably' or 'possibly' contaminated. So measured data was little available. After SAMASE-project closer investigations on contaminated sites has been continued as environmental authorities' normal environment protection work. Also regional environmental agencies have determined the persons responsible for the pollution or owners of contamined soil areas to make surveys on their sites. The amount of polluted areas has been arisen slightly because new cases are continually revealed.

\section{LEGISLATION}

Current legislation includes the concept of contaminated soil area. In the beginning of 1994 new Waste Act came into force. There are sections where e.g. pollution of soil is forbidden, responsibilities to report soil pollution in connection with selling land is determined and the function of the authorities is described.

Polluter pays -principle is still hard to follow especially at old polluted sites. The Waste Act does not concern pollution happened before 1994. Liabilities must be found using clauses from e.g. Chemical Law, former Waste Management Law or Water Law. Polluters have also been known to try to evade or escape their duty to clean up. Fortunately investigation and remedial work is often done voluntary. The increasing knowledge of environmental and health risks caused by soil pollution has started this tendency.

\section{FINANCING}

SAMASE-project estimated that the number of polluted land areas expected to require restoration over the next 20 years was put at around 1200, of which 800 are contaminated industrial and other such areas, over 300 old landfills and 35 mine tailing areas. The total volume of contaminated soil to be treated would exceed 10 million mé and the cost of restoration, by year 1994 reckoning, would be FIM 5.4 billion. Of this sum, restoration of polluted industrial areas would account for FIM 3 billion, landfills for FIM 1.1 billion and mine tailings areas for FIM 1.4 billion. If sites where the operations causing the contamination have ceased have to be restored with both government and municipal funds, each would pay FIM 1.1 billion. It is proposed that polluted land should be restored 
over a 20-year period, with the government and local authorities each contributing FIM 55 million a year to costs, on condition that no new major restoration needs emerge. This would leave FIM 3.2 billion to be paid by establishments and property holders (Puolanne et al., 1994).

The resources meant to promote the field of soil protection have increased propitious during last years in Finland. Funds from government, different foundations and private enterprises have made e.g. wide research programmes possible. Know-how is remarkable increased lately. Also a great number of remediation projects is the ground for contractors' better skills.

\section{METHODS USED FOR REMEDITION IN FINLAND}

Rapid progress has been made in restoration techniques. The main methods used in Finland are incineration, composting, stabilization in concrete, and treatment of soil air. Polluted land has also been isolated from its surroundings or the problem has simply been removed elsewhere - usually to a landfill. The latter cannot, however, be considered an appropriate measure in the long term, as the problem will still have to be confronted if the landfill is improved. The use of effective soil clean-up methods in Finland is hindered by the proliferation of relatively small contaminated sites in a large area; a compromise then has to be reached between use of the best available technology and reasonable cost (Puolanne et al., 1994).

\section{CONCLUSIONS AND FUTURE WORK}

Soil contamination is limited problem in Finland. Contaminated sites can be solved provided that they are identified and there is dedication to complete the task. New Waste Act and consciousness of soil pollution risks prevent new contamination of soil.

Developing work should be still done especially for research methods and risk analysis methods for contaminated soils. This has importance for correct decision making and dimensioning of remediation needs. Also remediation methods shoul be developed more environment and cost effective.

\section{REFERENCES}

Puolanne J., Pyy O. and Jeltsch U. (1994) Contaminated soil sites and their management in Finland. Contaminated soil site survey and remediation project; Final report. Memorandum 5/1994, Ministry of the Environment, Department for environmental protection, Helsinki, Finland. In finnish. 218 p. 